\title{
UNIQUE SELF SEARCH IN VOCAL JAZZ
}

\author{
Indrè Dirgèlaitė \\ Lithuanian Academy of Music and Theatre
}

\begin{abstract}
The paper reveals the phenomenon of jazz music and analyses the expression of vocal jazz in a historical, philosophical, and educational context. The historical origins of jazz are related to a community culture and to the natural and authentic creative process; inner freedom is one of the most significant aspects of jazz music, based on improvisation. The global practice of jazz vocal studies is predominated by a systemic approach that links the physiological, psychological, and mental levels. The study process is not separated from the personality (self) development and the creation of a sensitive and enabling relation culture. The paper presents a reflection on personal practical experience and is based on the data of a presentation Unique Self Search in Vocal Jazz: Jazz Voice + Theatrical Elements: Wider Opportunity for Self-Expression, given in the 2nd International Scientific Jazz Vocal Conference held in the Sibelius Academy (Helsinki, Finland).

KEY WORDS: jazz vocal, creativity, uniqueness, systemic approach.
\end{abstract}

\section{Anotacija}

Straipsnyje atskleidžiamas džiazo muzikos fenomenas, vokalinio džiazo raiška analizuojama istoriniame, filosofiniame ir edukaciniame kontekste. Istorinès džiazo muzikos ištakos susijusios su bendruomenine kultūra, natūraliu ir autentišku kūrybos procesu; vidinè laisvė yra vienas svarbiausių džiazo muzikos, paremtos improvizacija, aspektų. Pasaulinèje džiazo vokalo studijų praktikoje vyrauja sisteminis požiūris, susiejantis fiziologinị, psichologinị ir mentalinị lygmenis. Studijų procesas neatskiriamas nuo asmenybės ugdymo(-si), subtilaus ir igalinančio kultūros bei kūrybos santykio. Straipsnyje pateikiama praktinès patirties refleksija, remiamasi pranešimo „Unikalaus savęs ieškojimas vokaliniame džiaze: džiazo vokalas + teatriniai elementai: didesnès saviraiškos galimybès“, kuris skaitytas antrojoje tarptautinėje mokslinėje džiazo vokalo konferencijoje J. Sibelijaus muzikos akademijoje (Helsinkis, Suomija) duomenimis.

PAGRINDINIAI ŽODŽIAI: džiazo vokalas, kūryba, unikalumas, sisteminis požiūris.

\section{Introduction}

Jazz vocal studies are closely related to the search for one's own style, voice, and improvisational power. The process builds on the experience of foreign countries and includes a search for new, innovative solutions. The most important aspect is the discovery, cultivation, and enhancement of one's own self while knowing that each individual has a different holistic structure and is unique. The origins of jazz music are associated with the community-based African culture, therefore, one can often ask: "Is it possible to sing better than Afro-Americans? 
Can one have such a deep and expressive voice as the compatriots of jazz music?" However, is it really always necessary? Maybe it is more important to discover one's own individual style, to discover and improve one's own unique voice? Undoubtedly, it is easy to get lost in the styles of famous performers if one does not have creative courage and fails to realise that vocal jazz is an area that requires constant work and effort to combine the body, mind, and spiritual resources. In 2015, the Sibelius Academy in Finland held the 1st International Scientific Jazz Vocal Conference. Around 100 participants included vocalists, composers, arrangers, and educators from all over the world: USA, Germany, Sweden, Finland, Australia, the United Kingdom, Latvia, France, the Republic of South Africa, and many other countries.

The first day started with a question from Michele Weir, one of the most famous jazz vocal educators: "Who / what influenced you to one day understand that you wanted to sing jazz?" (I remember that, many years ago, her book Vocal Improvisation served for me as a key to the world of jazz vocal improvisation). Michele began with her personal story: the search for oneself as a jazz musician... And should jazz singing be cognitive or intuitive? The presenter summarised her reflections in a memorable phrase: "Sing from the heart, but prepare as a professional musician." Michele Weir talked about the risk of perfectionism and self-criticism and about the need for educators to be careful when working with students and their creativity in which a free soul lived. Too much criticism and pressure made students reluctant to take risks and try new things in creation and improvisation if they constantly felt criticised and heard "bad" or "wrong". According to Michele, it was important for a singer to strike a balance between risk, emotional vulnerability, and the technique and professionalism.

In Lithuania, the training of vocal jazz performers does not have an old tradition; more attention has been paid to instrumental music, often without sufficient consideration of jazz vocal studies as a separate field requiring specific professionalism and preparation. It does not suffice for a jazz vocalist to know the basics of harmony and to be able to improvise; their main instrument is voice, therefore, a continuous process of improvement and learning is necessary in order to discover and enhance their own uniqueness.

The aim of the paper is to reveal the opportunities of the search for the unique one's own self in jazz vocal, based on a theoretical discourse and practical experience.

The object of the paper is the search for the unique one's own self in vocal jazz. 
The methods: analysis of scientific literature, reflection on experience.

Methodological approaches of the research: a systems theory which emphasises the interrelation and interaction of individual elements of the system. That is relevant to the vocal jazz practice because it reflects a holistic, systemic approach to man and man's structural elements: body, mind, and spirit. The interaction and the totality of those structural elements is the basis of the jazz vocal practice. The systems theory is also relevant to the analysis of jazz music as a phenomenon with its historical origins and a consistent creative continuity. In the studies of jazz music, a humanistic approach is relevant which creates an enabling relationship between people. When each person is seen as an only and unique, confidence and faith in their own power are built which provide them with courage in a creative process. In such a way, an atmosphere of psychological freedom and security is created when "I must" becomes "I want and I can".

\section{Discursive analysis of the jazz music origins}

The origins of jazz music are related to the African community culture and its folklore tradition. Ritual music would accompany Africans through the most important moments of their lives: birth, weddings, and crossing into manhood used to be celebrations of all the community. Therefore music, which accompanied human life and helped people survive through the good and the bad, performed a social function, united the community, and gave strength to each community member (Klova, 2002). The statement was supported by the anthropological research which revealed a social function of arts in human life: to inspire for work, to elevate spiritually, to encourage in a fight, etc. (Harris, 1989).

African musical folklore is diverse and celebrates an entire human life: occasional ritual songs inspire soldiers and hunters for heroism, deaths are lamented, and victories are celebrated (Klova, 2002). In the course of history, the impact of Christianity and the culture of the white became evident. Therefore, one can argue that, in the course of history, the African folkore tradition provided one with an opportunity to survive and to strengthen the relationship with oneself, the closest family and one's national environment, the international world, and the transcendental world. The system is reflected in an ecological model below (see Fig. 1): 
Indrè Dirgèlaitė

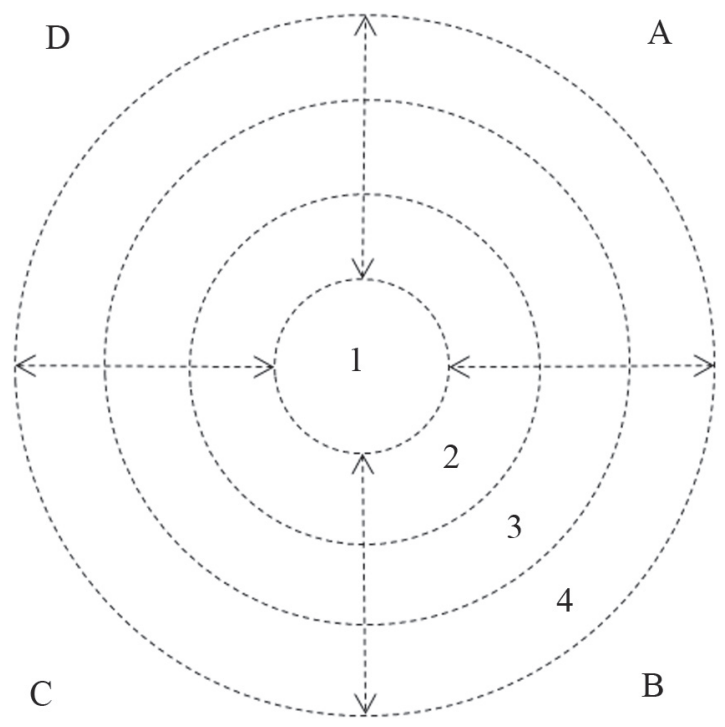

Fig. 1. An ecological model (Grenstad, 1996)

The four concentric circles mean different areas that each of us has a certain relationship with:

1. The intrapersonal area refers to an individual's inner life, thoughts, feelings, experiences, etc., as well as an individual's relationship with himself, his own identity and himself, and his experiences as an independent personality.

2. The interpersonal area refers to the closest national human environment and his relationships with close people, e.g. family, friends, colleagues and other people in the immediate surroundings.

3. The extrapersonal area refers to the surrounding international world and the human relationship with it. It includes things, technologies, knowledge, science, etc. The area also refers to the society as a whole, i.e. the immediate and a larger community, mankind, and human relations in it.

4. The transpersonal area refers to what is behind and above us and what we choose to believe and not to believe in and to base our lives on: religion, ideology, the philosophy of life and culture, etc. (Grenstad, 1996).

In African music, the aspect of improvisation stands out, and improvising is free and joyful: Africans enjoy music. Music becomes a form of communication 
and of a dialogue. Other important aspects of African music that affected the formation of jazz music include rhythmic freedom, rhythmic polyphony, rhythmic models, specificity of harmonies and a sound sequence system, responsorial singing, etc. (Gerulaitis, 1994; Klova, 2002).

In the 17th to the 19th century, about two million slaves were brought from Africa to the northern states of the USA, and about three million to the southern states. Their greatest assets were the language, traditions, and a lifestyle that provided them with the strength to survive and to create their own musical culture, the so-called American black music (Klova, 2002, p. 12). And again, the community tradition became a strength that provided an opportunity to maintain the identity in the most difficult circumstances by creating conditions for self-expression and self-realisation. Abraham Maslow (2006) named the following conditions: psychological freedom and psychological security, the absence of criticism and evaluation, and the experience of the process. Under the influence of other cultures, self-actualisation and values, resistance to the impact of an alien culture and the transcedence of culture become relevant themes.

The contact with the white music was inevitable: it happened through the attendance of church and other gatherings. Under the influence of the Christian culture, the tradition of work songs penetrated into church singing; around 1850, a new black ecclesiastic tradition was formed, Evangelical open-air rallies were gaining popularity, and a special form of a new ritual dance Sing Shout, as well as a spiritual, an archaic genre of spiritual choral singing of the North American black, came into being: the latter's plot was based on the Bible and life stories of slaves. In the 19th century, it turned into an independent polyphonic form, affected also by psalms sung by the white Christians. The spiritual can be regarded as one of the main sources of jazz music due to its characteristic elements: improvisation, the responsorial technique, off beat ("swinging"), stylishly delayed rhythm that laid the foundation for swing; dirty tones, blue notes, off pitch ("non-musical" notes apppearing in a melody as various shouts and speech intonations), etc. (Klova, 2002, p. 14).

In Lithuania, jazz celebrated its 50th anniversary in 2011. Such a chronology was proposed by Liudas Šaltenis (Molokojedovas, 2002). Olegas Molokojedovas (2002), who studied the birth and development of jazz in Lithuania, placed special emphasis on the composers and groups who affected the development of jazz music in Lithuania: V. Ganelinas, R. Rumelaitis, V. Ganelin's trio, P. Vyšniauskas, V. Čekasinas, O. Molokojedovas, A. Jofe, V. Labutis, S. Sasnauskas, S. Šiaučiulis, V. Grubliauskas, A. Anusauskas. D. Praspaliauskas, V. Tarasovas, L. Mockūnas, etc. 
In the works of the Lithuanian jazz creators, the Lithuanian folklore tradition has been taking an increasingly important place. One can take a discursive look at the ancient Baltic culture in the context of the African culture,. Giving meaning to the life cycles is close to the ancient Baltic tradition when the most important transformations of human life, such as baptisings, weddings, or funerals, were experienced in a meaningful way. The ancient Baltic calendar, Rédos ratas, revealed the relationship between man and nature reflected in the narrative and singing folkore (Žarskus, Patackas, 2002). The songs born in the process of the community life - calendar songs, family celebrations (wedding, baptising, funeral) songs, war songs, and work (milling, ploughing, haymaking, harvesting, fishermen's, etc.) songs made human life easier and calmer and encouraged hope and faith. The old work songs (including sutartiness, Lithuanian polyphonic part songs) were characterised by a specific rhythm that brought people together and organised them for common activities. In that live folklore tradition, children took an active part; they also created, and children's songs are abundant (Dundulienè, 2005; Jareckaitè, 1993; Balys, 2013, etc).

In the period of Christianity, the old funeral laments were substituted for by Christian hymns, and spirituals and worship hymns became increasingly popular in Lithuania. In the course of history, the creativity of the nation survived, and music creation tended to become more active in the periods difficult for the nation: the belief in freedom and sorrowful contemplations of their difficult situation unfolded in partisan songs; the songs of deported Lithuanians were full of the longing for Homeland and Faith; and the songs of Rebirth encouraged solidarity of the nation in standing up and fighting for freedom. Some of those songs created by individual authors became folk songs. The world came to know Lithuania as a country of a "singing revolution". Thus, the tradition of communal singing in Lithuania has never been interrupted: it accompanied, and will accompany, each Lithuanian from the cradle to the grave. The period (1988-1991) has not yet been sufficiently explored and generalised, and it is open to the studies of musicologists, culturologists, educators, anthropologists, and scholars and professionals of other areas.

Both in the African and Lithuanian folklore traditions, one can also see the aspects of intensive therapeutic life (the effect of therapy is presented in A. Kočiūnas (ed.) 2002). The concepts relevant to that kind of therapy include Faith, Hope, Love, Life, Freedom, Spirit, Prayer, Infancy, Childhood, Old Age, and others. Thus, the communal spirit is likely to have been healing human life and giving the courage to create.

In the summary of the jazz music origins, one could refer to the system of changes in the lifestyle models presented in E. Liebert's (2002, p. 25); the birth of 
jazz as a phenomenon and its formation had the following stages: 1) The port of arrival in the planet: the birth of the authentic African folkore; 2) Rough and bold: the development of an authentic culture, while making efforts to survive in most complex situations and relying on comunion as a value; 3) a good neighbourly community: the slavery called for solidarity, and simultaneously for listening to the characteristics of other cultures, including the Christian one; 4) Self-helpers: creative efforts to maintain one's own identity under the impact of other cultures and the birth of the spiritual as a genre; 5) Combine all things: the synthesis of cultures in the further and contemporary development of jazz music.

\section{Improvisation as a result of creativity}

One of the topical theoretical ideas in the analysis of the aspect of creativity in the contemporary society is the humanistic-existential theory. That approach to man deals with more positive and optimistic aspects of human life. The contribution of Abraham Maslow (1908-1970) and Carl Rogers (1902-1987) to the said area is substantial. Both of them were interested in human lives and examined the circumstances that allowed people to live a more positive, productive, and happier life. Maslow saw the need for personal development as "the highest achievement everyone desires, but only a few achieve. Maslow's Pyramid, or the Hierarchy of Needs, is a document best illustrating his research. Theories of needs have been mainly analysed by representatives of social sciences who relate the meeting of needs to the enabling process. Increasingly frequently, the enabling of schoolchildren and students has been discussed. The idea of a learning society poses challlenges to the system of education. The educational process is seen holistically, by actualising the aspects of a dialogue and reflection and the opportunities of application of new teaching / learning styles (Duoblienè, 2006).

Carl Rogers was a psychotherapist who explored the necessary conditions for a person to grow and develop despite the age and the life stage. In 1951, he argued that the organism had one basic tendency and striving - to actualize, maintain, and enhance the experiencing organism. A person who wants to help others develop that potential should show an unconditional positive attitude. The approach of respect and attention at the time of revaluation of values is accepted by people in misery as a kind of medicine returning strength (Mayers, 2000, p. 489).

Various authors have named different, even contradictory, features typical of a creative personality: the ability to take independent decisions, perseverance and dominance; seclusion and calmness, an interest in ideas, and not things; the ability 
to identify oneself, to express feelings and experience; passive emotional adaptation, self-discipline, slightly slower psychosexual development, etc. (Grakauskaite-Karkockienè, 2003). E. Fromm (2008) distinguished between two meanings of creation; one meant that something new was created. That kind of creation was predetermined by one's talent, genes, learning, practice, as well as economic and social conditions enabling a personality to develop his talent. The other meaning of creation was a creative attitude that could manifest itself without creating anything new. A creative attitude, or creativity as a feature of character, was "the ability to see or to respond". The ability to see another person required objectivity derived from inner maturity, reducing the projection and distortions inherent in neurotics. The ability to respond demanded to fully react to reality.

In the studies of a creative personality in the initial stage of creation, Maslow (2006) noted that, at the time of inspiration, a person tended to experience just that particular moment, forgetting the past and the future. He got completely immersed in the present moment, in what was happening "here and now". Sometimes he forgot his own self. The moment was experienced as the merging with reality, accompanied by bliss, enthusiasm, ecstasy of admiration, and exaltation. The author was surprised that such an overwhelming experience was most frequently perceived as supernatural, unnatural, and exceptional. Maslow called that particular experience "peak experience" and regarded it as natural. Those "peak experiences" could manifest themselves in different areas, such as creation, love, enlightenment, and mystic experiences. They happened "here and now" and were the most significant ones, able to change the human life. A person would become holistic, love the world, and accept other people with no fear, anxiety, defense, or control; he would become spontaneous, courageous, and strong. Such experiences could not be caused by conscious and willful efforts (Grakauskaitè-Karkockienè, 2003). One of those experiences was "noticeable total expressiveness and uniqueness". Full spontaneity ensured and enabled the manifestation of the nature and style of a functioning object; it ensured naturalness, genuineness, and the absence of cunningness. Being unique meant the absence of need to direct others, manage, or manipulate. Both a jazz musician and his audience, "involved" in the process of creation, were likely to have those "peak experiences".

To become a god improviser, talent and phantasy do not suffice: it is necessary to work hard and patiently. The improvement of the vocal improvisation skills is an ongoing and never ending process. Vocal improvisation can be seen as a musical adventure, and primarily not so much as an effort to look "right", but rather as giving oneself freedom and enjoying creation. Famous jazz musicians find new, surprising ways to express themselves through jazz improvisation. After a while, 
something new appears, something that has not yet been heard in jazz music. The musician seems to be creating his own language. In the dictionary of international words, improvisation is defined as "a work created through performance without pre-preparation" (Dictionary of International Words, 2004, p. 314). "In theory", improvisation must be spontaneous, however, there is a direct connection between the time spent by the musician for his education and his competence. Instrumentalists have long understood that in order to be a good jazz musician, they need not only to play a lot: comprehensive education is necessary. Vocalists improve their improvisational skills not so much as instrumentalists, but there is no reason for them not to do that. Moreover, by making breaks, they can train not only their voice, but also other musical abilities (e.g., internal and harmonic ear or the skills of solmisation of an unnown musical text). According to M. Weir (1994) vocalists' daily activities usually look like that:

- recording and singing together with improvisations of good jazz musicians;

- work with separate parts of jazz improvisations, including the training to hear the chord sequence of a composition, learning phrases based on harmonic "clichés", learning syllables attractive and suitable for improvisation, etc.

- simply finding time to improvise with recorded or "live" accompaniment;

- experimenting with improvisation, and simultaneously trying to use what has already been learnt. That may be just a fun time. It's important to know where and when to draw the line and start developing your own improvisation.

To quote Dee Dee Bridgewater, “A jazz singer should never be afraid to take risks. In art, in music, the most memorable creators are those who are not afraid to take risks and have created a style and their own language, which is characteristic only of them. Music is worthless if it is not in harmony with the creator's soul..." In a democratic society, an individual and his activities are viewed holistically (all-embracing), actualizing his physical, mental, and spiritual powers. In the studies and practice of jazz music, an environment emphasised by representatives of humanistic philosophy should predominate, as it creates conditions for the dissemination of creativity: psychological freedom and psychological security; criticism and evaluation are to be clearly separated from personality evaluation. The process should promote human self-confidence and reveal his inner powers. Then the opportunity to create and to involve others in the process appears. 
Jazz music is inseparable from the relationship between creativity and cognitive functions (perception, thinking, imagination, and intelligence). Joy Paul Guilford, 1957 (after Grakauskaite-Karkockienè, 2003), when discussing the creative abilities necessary in art, referred to the following: to perceive the relationship and to create a certain structure, predetermined by the characteristics of the meaning. Therefore, one can argue that creativity is characterised by respective thinking strategies. The aspects identified by the author are very suitable for jazz music, as through the mastering of the theoretical foundations of jazz music, the opportunities for creation open up: looking for meanings and relationships and choosing strategies. Famous jazz musicians share their memories: "When you are young and you do not have sufficient knowedge and skills of harmony to create your own solo, you start copying things that sound good in solo parts of other musicians" (Barnny Bailey; after Weir, 1994, p. 95); "I decided that the best thing I could do was to copy the solo part note by note and to compare it with the harmony of the composition, to analyze the relationship of the played note with a specific chord. In that way, my "vocabulary" was enriched" (Art Farmer; after Weir, 1994, p. 95).

Just as children learn to speak their native language by imitating adults, young musicians also try to learn the jazz language by imitating experienced jazz musicians. In the long run, the musician creates his original "vocabulary" which becomes recognizable among all others. When listening to good jazz musicians, we find the sound colors and characters that are typical only of that artist as part of his personality.

\section{Reflection on personal experience}

For over a decade, I have been working as a singing teacher with actors and singers and giving workshops in European higher schools. I am a professional jazz singer. It is a special gift for me to work with people from different fields. I found some answers for myself about psychological and mental uncertainty and physical timidity. It inspired me to carry out research on how interdisciplinary courses can help singing and acting students open up and promote their development. The more I search, the more I understand how important it is to listen to oneself, to know oneself, to find one's own authentic expression, and to trust oneself. That is why my paper presents a holistic approach to jazz voice studies, i.e. vocal expression involving human physical-mental-psychological-emotional and spiritual levels. It is useful to understand how one's singing combines with movement, breathing, and sound in an integrated expressive action and how integrated theatrical 
elements and movement-based exercises work in voice classes. It is also useful to become familiar with one's own physiology and anatomy and to let one's breathing freely relate to thoughts and feelings. Free breathing helps to free your thoughts and mind. According to M. Lugering (2007), "Since breath and voice lie at the intersection of the material and the non-material, the work can also assist in creative, intellectual, and spiritual growth". For many singers and actors, work on range, interpretation, and improvisation is more than the enhancement and extension of the technical instrument or gaining theoretical knowledge; it means extending and redefining of who they are.

A systemic look at vocal jazz practice reveals two traditional and controversial scientific and philosophical propositions:

1. My Mind and Body are One (Neuroscientist Antonio Damasio: The human brain and the rest of the body constitute an indissociable organism... The organism interacts with the environment as an ensemble: the interaction is neither of the body alone nor the brain alone).

2. My Emotions and Feelings are an Integrated Mental and Physical Experience (Embodied cognition is a revolutionary way of thinking about human reasoning, which suggests that the content of the human mind-ideas, meaning, understanding, precepts and principles - are shaped and developed through physical experience (Internet Encyclopedia of Philosophy [refereed], 8 July 2005) (Lugering, 2007, p. 20-21).

When working with students, I notice how important it is to create a supportive and positive relationship that promotes creativity and self-knowledge. No methodology will be effective if the learner feels uncertain about himself, fearful of being mistaken and risking. Jazz vocal studios are a long journey toward oneself. According to M. Lugering (2007, p. 86), "Work on developing a flexible body structure often regimes a redefining of who we think we are and how we perceive ourselves". The road to fluid flexible expression is a complex human journey; for a singer and an actor work on range is more than strengthening and extending the technical instrument: it means extending and re-defining who they are.

A holistic approach reveals how fragile, sensitive, and indeterminate the practice of vocal jazz is. My practical teaching experience suggests that the learners who find it the most difficult are the ones who expect a quick result and who predict the result, based on preconceptions. Often those are result-oriented, but not processoriented individuals. The success or interruption of studies is also predetermined by the previous experience in music practice. To quote CVT Technique developer 
Cathrine Sadolin, "Of course it is requires practice to sing professionally, but when you know how the voice works and how to use its natural functions you will be able to learn most of what is required. Singing techniques are mostly about removing the constrictions to allow the voice to work freely" (Sadolin, 2000, p. 5). Particularly in interpretation and improvisation, we use different sound colours and a rich sound vocabulary to express our thoughts, to tell our story, so it is important to have a possibility to do it freely, with no body restrictions and psychological or mental limitations.

The whole process of vocal jazz studies is based on a holistic approach. The unity of the body, mind, and soul is an integral part of jazz vocal practice. Frequently, vocal jazz practice raises various problems and obstacles, often reflecting classical approaches and theoretical perspectives. Bound flow occurs when one part of the body is:

- Charging when it ideally should be releasing.

- Contracting when it ideally should be expanding.

- Making contact when it ideally should be withdrawing (Lugering, 2007, p. 97).

Any of these misdirected actions disallow the body to flow freely from the centre to the periphery. Then it is important to look at the vocal studies as an integrated phenomenon, to apply different methodologies, and to take into account each learner's individual qualities and experience. Frequently, a variety of the forms of activity is also helpful - individual work allows one to take a closer look at oneself, while group activities provide courage and experiential learning opportunities. A variety of techniques are used to help one to look at jazz vocal more broadely, to find one's own unique character, to get rid of body restrictions and of negative emotional and body experiences. Those include:

- Expressive action.

- Voice, text, and body synchronization.

- Yoga / singing yoga.

- Fitzmaurice technique.

- Alexander technique.

- Fendelkrais method.

- Suzuki technique.

Each one finds the best method for oneself. That is a long road of learning, discoveries, and doubts. Techniques provide an opportunity to move and sound from the deeper wisdom of the body, giving yourself MENTAL and EMOTIO- 
NAL freedom with no BODY RESTRICTIONS; support creative, intellectual and spiritual growth; and help to find new and authentic sound colours. The Body and Mind are Free and Flexible, Thoughts and Feelings Imprinted in our Body go Free through the Sound.

\section{Conclusions}

The origins of jazz music are associated with the communal Afno-American culture. Jazz music formation underwent tranformations: the development of an authentic culture, in an effort to survive in the most difficult situations and to find support in communion as a value - national cultural solidarity, and simultaneously close watching of the characteristics of other cultures, including the Christian one: creative efforts to maintain one's own identity under the influence of other cultures, the birth of spiritual as a genre - the synthesis of cultures in the further and contemporary development of jazz music. As proved by a discursive view of Lithuanian national culture, one can argue that even to date, communal singing remains a relevant identity: from work songs, war songs, partisan and deportees' songs accompanying the periods of threat to the nation - to the singing revolution. Folk creation has been increasingly frequently used in the contemporary jazz music.

The source of jazz music vitality is creativity. The humanistic perspective that helps a person to feel bold and valuable is an important aspect in it. Without psychological freedom and a secure atmosphere, it is hard to imagine a successful process of vocal jazz studies and practice. That is a long road towards oneself through getting to know and absorbing the work of famous performers, through the acquisition of the basic knowledge of harmony and improvisation, one looks for one's own authentic style and sound. It is important not to be afraid to take risks, to feel free, to believe and to trust the process by enjoying creative experiences "here and now".

The basis of vocal jazz practice is a holistic approach to man as a unity of body, mind and spirit. Very often, body restrictions that prevent free formation of sound and full expression of oneself in improvisation are related to psychological and emotional causes. Therefore, the practice and techniques of professional development are very diverse: they include yoga, Suzuki and Alexander practice, and elementary vocal exercises. Nevertheless, the holistic-systemic approach to the process that involves physiology, mind, psychology, and emotional and spiritual human levels remains an essential basis of professional development in the practice of vocal jazz. 
Indrè Dirgèlaitė

\section{Literature}

Balys, J. (2013). Lietuvių kalendorinès šventès. Iš Jono Balio palikimo. Vilnius: Mintis.

Dundulienė, P. (2005). Lietuviu kalendorinès šventès. Tradicijos, papročiai, apeigos. Vilnius: Mokslo ir enciklopedijų leidybos institutas.

Duoblienè, L. (2006). Šiuolaikinè ugdymo filosofija: refleksijos ir dialogo link. Vilnius.

Fromm, E. (2008). Pabégimas iš laisvès. Verba Vera.

Gerulaitis, V. (1994). Muzikos stilių raida. Vilnius: Muzikos švietimo centras.

Grakauskaitė-Karkockienè, D. (2003). Kürybos psichologija. Vilnius: Logotipas.

Grenstad, N. M. (1996). Mokytis - tai atrasti: susiliejančio ugdymo principai ir praktiniai darbo būdai. Vilnius: Apostrofa.

Harris, M. (1998). Kultūriné Antropologija. Vilnius: Tvermè.

Jareckaitė, S. (1993). Muzikinio ugdymo bruožai. Vilnius: Lietuvos mokytojų kvalifikacijos institutas.

Klova, A. (2002). Džiazo šaknys. Džiazo istorija (autorių grupè). Vilnius: Kronta.

Kočiūnas, R. (1999). Grupine psichoterapija Lietuvoje. Vilnius: Via Recta.

Lugering, M. (2007). The Expressive Actor: integrated Voice, Movement and Acting Training. Portsmouth, NH: Heinemann.

Liebert SNJM, E. (2002). Gyvensenos modeliu kaita: suaugusiujų raida dvasiniame vadovavime. Kaunas: KRC. Mayers, D. G. (2000). Psichologija. Kaunas: Poligrafija ir informatika.

Maslow, A. (2006). Motyvacija ir asmenybe. Vilnius: Apostrofa.

Sadolin, C. (2000). Complete Vocal Technique. Copenhage: CVI.

Tarptautinių žodžiu žodynas. (2004). Vilnius: Alma littera.

Weir, M. (2001). Vocal improvisation. New York: Advance Music.

Internet Encyclopedia of Philosophy [refereed], 8 July 2005. 